University of Nebraska - Lincoln

DigitalCommons@University of Nebraska - Lincoln

1984

\title{
Effect of Various Dietary Arginine: Lysine Ratios on Performance, Carcass Composition, and Plasma Amino Acid Concentrations of Growing-Finishing Swine
}

\author{
L. C. Anderson \\ Golden Sun Feeds Inc.
}

A. J. Lewis

University of Nebraska-Lincoln, alewis2@unl.edu

E. R. Peo, Jr.

University of Nebraska-Lincoln

J. D. Crenshaw

University of Nebraska-Lincoln

Follow this and additional works at: https://digitalcommons.unl.edu/animalscifacpub

Part of the Animal Sciences Commons

Anderson, L. C.; Lewis, A. J.; Peo, Jr., E. R.; and Crenshaw, J. D., "Effect of Various Dietary Arginine: Lysine Ratios on Performance, Carcass Composition, and Plasma Amino Acid Concentrations of GrowingFinishing Swine" (1984). Faculty Papers and Publications in Animal Science. 666.

https://digitalcommons.unl.edu/animalscifacpub/666

This Article is brought to you for free and open access by the Animal Science Department at DigitalCommons@University of Nebraska - Lincoln. It has been accepted for inclusion in Faculty Papers and Publications in Animal Science by an authorized administrator of DigitalCommons@University of Nebraska - Lincoln. 


\title{
EFFECT OF VARIOUS DIETARY ARGININE:LYSINE RATIOS ON PERFORMANCE, CARCASS COMPOSITION AND PLASMA AMINO ACID CONCENTRATIONS OF GROWING-FINISHING SWINE ${ }^{1,2}$
}

\author{
L. C. Anderson ${ }^{3}$, A. J. Lewis ${ }^{4,5}$, E. R. Peo, Jr. ${ }^{4}$ and J. D. Crenshaw ${ }^{4}$ \\ University of Nebraska, \\ Lincoln 68583
}

\begin{abstract}
Summary
Crossbred growing-finishing pigs (112 barrows, 48 gilts) were used to determine the effect of reducing excess dietary arginine, through feedstuff variation, on performance, carcass composition and plasma amino acid concentrations. Diets contained five, four, three or two times the NRC requirement for arginine. Lysine in all diets was formulated to be equal to NRC requirements, and all diets contained at least $100 \%$ of the NRC recommendations for all other essential amino acids. Initial weight, final weight and days on test for the grower phase were $26.7 \mathrm{~kg}, 44.2 \mathrm{~kg}$ and $28 \mathrm{~d}$, respectively. Weight gain and gain/feed were not different among treatments but feed intake showed a quadratic response during the grower phase, being highest at four times the NRC requirement for arginine. Initial weight, final weight and days on test for the finisher phase were $44.2 \mathrm{~kg}, 96.9 \mathrm{~kg}$ and $67 \mathrm{~d}$, respectively. Weight gain during the finisher phase and for the total experiment exhibited a quadratic response, being highest for the pigs fed the intermediate arginine levels. Gain/feed for the finisher phase followed the same trend as weight gain. Feed intakes for the finisher phase and total experiment were not different among treatments. Carcass data were collected on all
\end{abstract}

\footnotetext{
${ }^{1}$ Published as Paper No. 7098, Journal Series, Ne braska Agr. Exp. Sta. Research reported was conducted under Project 13-052.

${ }^{2}$ The technical assistance of Mary B. Barnes and Diana $\mathbf{J}$. Smith is gratefully acknowledged.

${ }^{3}$ Current Address: Golden Sun Feeds Inc., Grinnell, IA 50112 .

${ }^{4}$ Dept. of Anim. Sci.

${ }^{5}$ To whom reprint requests should be addressed.

Received March 7, 1983.

Accepted July 18, 1983.
}

barrows. There were no differences in hot carcass weight or adjusted average backfat among treatments. Loin eye area and percentage of lean decreased linearly as arginine level decreased in the diet. Plasma urea, arginine and orthinine concentrations decreased linearly with decreasing dietary arginine. Plasma lysine exhibited both a quadratic and a cubic response. The data indicate that reducing excess dietary arginine had little effect on performance or carcass composition and no consistent effect on plasma lysine of growing-finishing swine.

(Key Words: Growing-Finishing Swine, Arginine, Lysine, Performance, Carcass, Plasma Amino Acids.)

\section{Introduction}

In most swine diets lysine is the first limiting amino acid. Diets are generally formulated to meet the minimum lysine levels required for maximum weight gain; there is rarely an excess amount of lysine. Other amino acids, however, are found in quantities that greatly exceed the pig's requirement. Arginine is one of these amino acids.

Research with chicks (Jones, 1964; Boorman and Fisher, 1966; Jones et al., 1967; D'Mello and Lewis, 1970) has shown that excess lysine exerts adverse effects on arginine utilization, thereby increasing the arginine requirement. The effects are reversed by arginine supplementation.

Using a pig fitted with reentrant cannulae in the small intestine, Buraczewski et al. (1970) found that when they increased either arginine or lysine concentrations in the small intestine by relatively large additions of crystalline amino acids, the absorption of the other amino acid was reduced. Thus, it is possible that in practical swine diets, if the arginine content is decreased, there may be an increase in lysine 
utilization. This would reduce the total amount of lysine needed in the diet. As different feedstuffs contain different amounts of arginine and lysine, dietary arginine content and arginine:lysine ratio can be changed by altering dietary ingredients. In this manner, the effects of various dietary arginine contents can be examined using normal dietary ingredients without having to employ additions of crystalline arginine. This avoids possible differences between utilization of crystalline arginine and the arginine in feedstuffs (Matthews, 1975a,b).

The objective of this experiment was to determine the effect of diets formulated to contain various arginine levels and arginine: lysine ratios on performance, carcass composition and lysine utilization of growing-finishing swine.

\section{Materials and Methods}

Animals and Data Collection. One hundred sixty crossbred pigs (112 barrows, 48 gilts) with an average initial weight of $27 \mathrm{~kg}$ were allotted to four treatment groups with five pens/treatment and eight pigs/pen. The allottment design was a randomized complete block in which ancestry and sex were balanced within blocks. Pigs were housed in a modified-open-front building and were allowed ad libitum access to feed and water. Pig weight and feed consumption data were collected biweekly. Each replicate was removed from the experiment after $95 \mathrm{~d}$. At the termination of the experiment, a blood sample was collected from each pig. Carcass composition was measured on barrows (28/ treament) only. Backfat was measured perpendicular to the chine opposite the first rib, last rib and last lumbar vertebra. The mean of the three measurements was adjusted to a constant hot carcass weight. Carcasses were split between the 10th and 11 th ribs, and loin eye muscle tracings and fat depth measurements were taken. Loin eye area was determined using a polar compensating planimeter ${ }^{6}$, and was also adjusted to a constant hot carcass weight. The adjustments were made by using hot carcass weight as a covariable in the analysis of

\footnotetext{
${ }^{6}$ Model 40, Lasico. 2451 Riverside Dr., Los Angeles, CA 90039.

${ }^{7}$ AgNet Feedmix Swine Formulation Program, Univ. of Nebraska, Lincoln 68583.
}

data. Percentage of lean was calculated using the equations recommended by NPPC (1976).

Diets and Diet Analysis. Diets for the growing phase ( $28 \mathrm{~d}$; avg wt 27 to $44 \mathrm{~kg}$ ) and finishing phase (67 d; avg wt 44 to $97 \mathrm{~kg}$ ) are presented in tables 1 and 2 , respectively. The diets were formulated using a computer formulation matrix ${ }^{7}$ with normal feedstuff limitations. Treatments were calculated to meet the NRC (1979) requirement for lysine for the growing and finishing periods $(.70$ and $.61 \%$, respectively) and to contain five, four, three and two times the NRC requirement for arginine (growing phase $.20 \%$; finishing phase .18\%). All diets were formulated to contain at least $100 \%$ of the requirement of all other essential amino acids. Crude protein content, however, was not constrained within the formulation model.

Diets were analyzed for protein, $\mathrm{Ca}$ and $\mathrm{P}$ (AOAC, 1980) and gross energy content (Parr Instrument Co., 1978) and the results are included in tables 1 and 2 . Feed samples were hydrolyzed in $6 \mathrm{M} \mathrm{HCl}$ under $\mathrm{N}_{2}$ for $20 \mathrm{~h}$. The hydrolyzate was analyzed for arginine and lysine using an automated ion-exchange separation (Blackburn, 1978), followed by fluorimetric detection (Benson and Hare, 1975). Arginine and lysine values for the growing and finishing phases are included in tables 1 and 2, respectively.

Blood Sample Preparation and Analysis. Blood samples were obtained from the anterior vena cava or an adjoining vein using 20 gauge needles. Samples were collected in $10-\mathrm{ml}$ evacuated blood collection tubes containing sodium heparin. Plasma was separated by centrifugation at $1,116 \times \mathrm{g}$ for $15 \mathrm{~min}$. Individual plasma samples from each pig were analyzed for urea using an automated procedure described by Marsh et al. (1965). One milliliter of plasma from each pig was pooled by pen to make a composite sample for each pen. The pooled plasma samples were deproteinized using $30 \mathrm{mg}$ of sulfosalicyclic acid/ml of plasma (Perry and Hansen, 1969). Deproteinized plasma was analyzed for arginine, lysine and ornithine as described for diets.

Statistical Metbods. Response criteria were analyzed using analysis of variance techniques appropriate for a randomized block design and orthogonal polynomial contrasts to separate treatment effects (Steel and Torrie, 1980). The Statistical Analysis System (SAS, 1979) was used for computation. 
TABLE 1. COMPOSITION OF GROWING DIETS

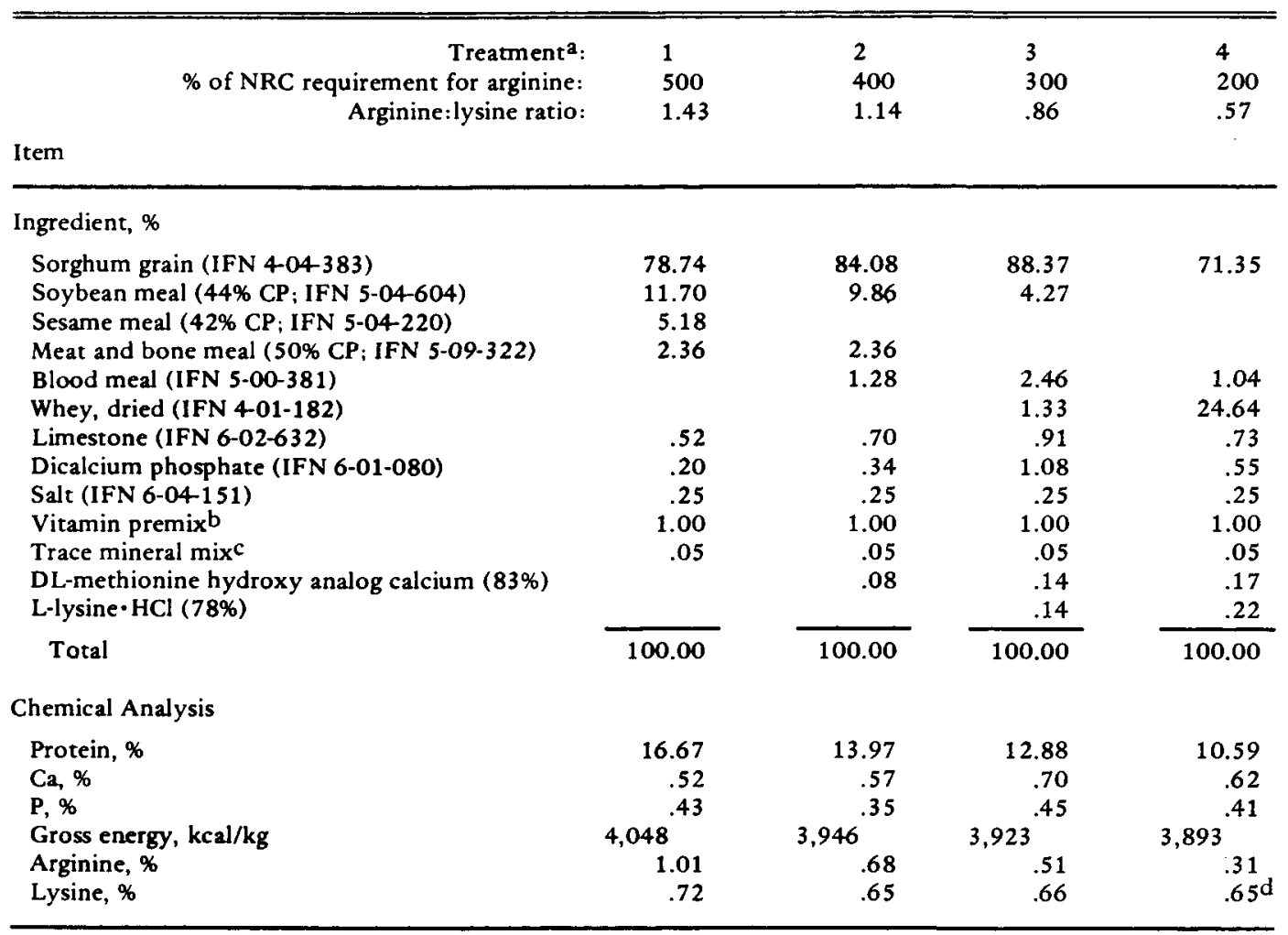

${ }^{\mathrm{a}}$ Fed to pigs from 27 to $44 \mathrm{~kg}$.

${ }^{b}$ Provided the following per $\mathrm{kg}$ of diet: vitamin $\mathrm{A}, 3,300 \mathrm{IU}$; vitamin $\mathrm{D}_{3}, 440 \mathrm{IU}$; vitamin E, $22 \mathrm{IU}$; riboflavin, $2.2 \mathrm{mg}$; d-pantothenic acid, $13.2 \mathrm{mg}$; niacin, $17.6 \mathrm{mg}$; choline chloride, $110 \mathrm{mg}$; vitamin $\mathrm{B}_{12}, 22 \mu \mathrm{g}$; menadione sodium bisulfate, $2.2 \mathrm{mg}$; ethoxyquin, $4.4 \mathrm{mg}$.

${ }^{\mathrm{C}}$ Provided the following in $\mathrm{mg} / \mathrm{kg}$ of diet: $\mathrm{Zn}, 100 ; \mathrm{Fe}, 50 ; \mathrm{Mn}, 27.5 ; \mathrm{Cu}, 5.0 ; \mathrm{I}, .75$.

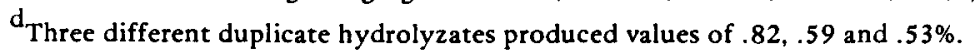

\section{Results and Discussion}

Performance results for the growing and finishing phases and the total experiment are presented in table 3. Average daily feed intake (ADFI) during the growing phase responded quadratically $(\mathrm{P}<.05)$ to decreasing arginine content. Intake increased as dietary arginine content decreased from five to four times the NRC requirement, but further reductions of arginine resulted in a decrease in ADFI. Pigs fed treatment 1 consumed the least feed during the growing phase. Although the excess arginine present in this diet may have been responsible for the reduced intake, this was the only growing diet that contained sesame meal. Thus, it is possible that poor palatability or some other factor(s) associated with sesame meal may have been at least partially responsible for the dif- ference. Average daily gain (ADG) and feed efficiency $(G / F)$ were not different $(P>.10)$ during the growing period.

During the finishing phase, ADFI was not different ( $P>.10)$ among treatments; however, ADG was affected quadratically $(P<.05)$ and $\mathrm{G} / \mathrm{F}$ exhibited a similar quadratic trend $(\mathrm{P}<.10)$. Both ADG and G/F were increased by the initial lowering of dietary arginine content, but not by subsequent arginine reductions.

When considered over the total experiment, ADG exhibited the same quadratic response to treatment $(\mathrm{P}<.05)$ as was observed in the finishing phase. Pigs fed the intermediate levels of arginine had the highest ADG. The relatively low ADG of pigs fed treatment 4 was unexpected. A possible explanation for low ADG is the low crude protein content of this diet. 
Corley and Easter (1980) found that total N limited the growth response of pigs fed $10 \%$ crude protein diets containing supplemental crystalline amino acids. Even though all experimental diets in the present experiment were formulated to contain at least $100 \%$ of the NRC (1979) requirement for each essential amino acid, treatment 4 did contain less protein $(10.97 \%)$ than is normally present in finishing diets. There were no treatment differences $(P>.10)$ in either ADFI or $G / F$ over the total experiment.

Normal corn-soybean meal diets contain four to five times the NRC requirement of arginine for growing-finishing pigs. The current NRC requirements for arginine were utilized in the formulation of diets for this experiment. However, it was recognized that the requirements for arginine are based on very few experimental data, and that estimates may be revised as more data become available. The performance data from this experiment indicate that no benefit accrues from reducing the dietary arginine content supplied by feed ingredients to below four times the current NRC requirement.

Miller et al. (1981) found no significant differences in the performance of growing ( 20 to $60 \mathrm{~kg}$ ) pigs fed two different diets that varied in arginine:lysine ratio $(1.2: 1$ vs $1.0: 1)$. The arginine:lysine ratio was not altered as dramatically as in our present study. Although there was a tendency for pigs fed "a better balance of amino acids" (1.0:1 arginine:lysine) to perform better than those fed a corn-soybean meal diet (1.2:1 arginine:lysine), differences were not statistically significant.

Plasma urea and amino acids concentrations are listed in table 4. Plasma urea decreased linearly $(\mathrm{P}<.001)$ as the dietary arginine con-

TABLE 2. COMPOSITION OF FINISHING DIETS

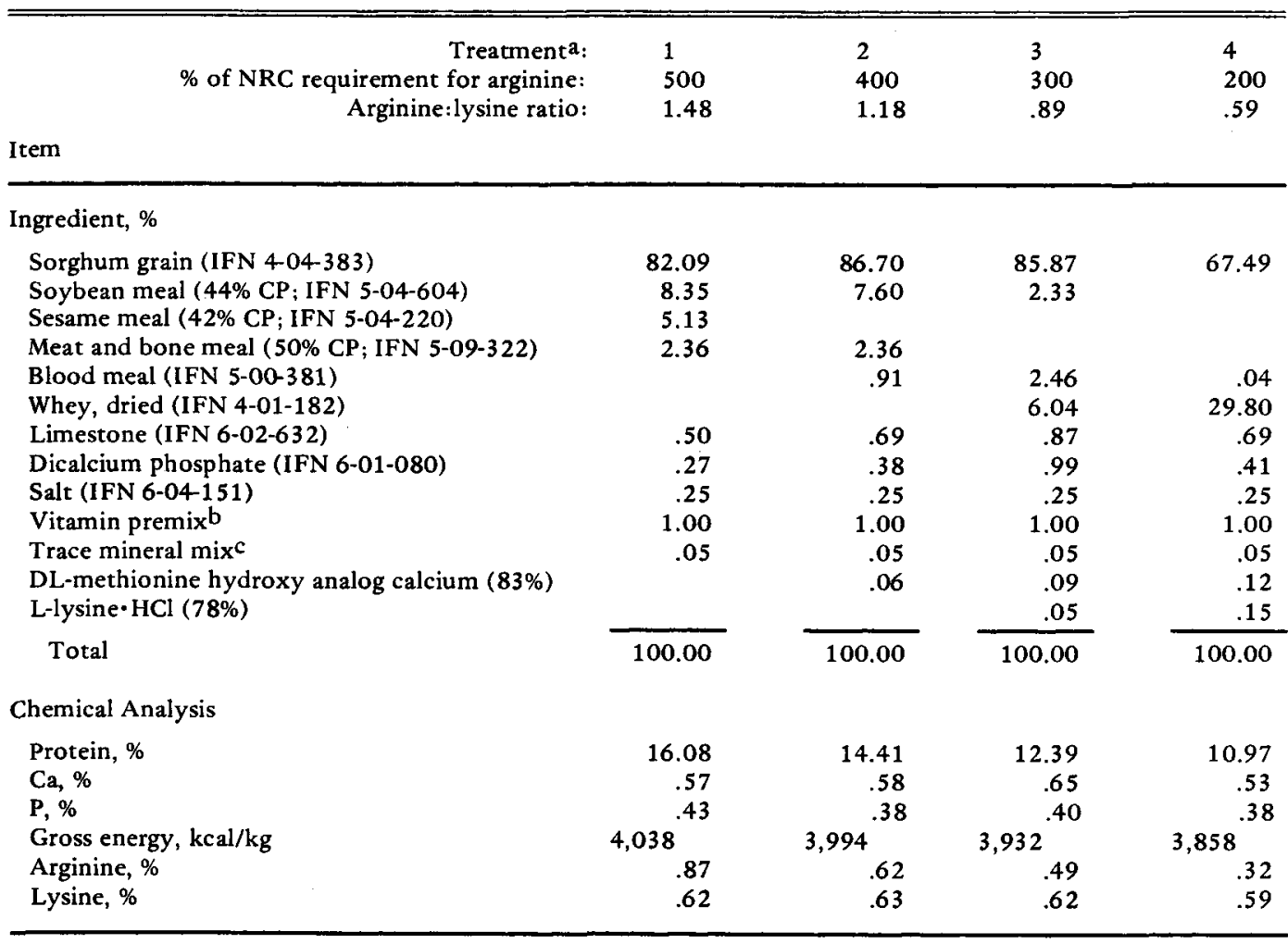

\footnotetext{
${ }^{\mathrm{a}}$ Fed to pigs from 44 to $97 \mathrm{~kg}$.

${ }^{b}$ Provided the following per $\mathrm{kg}$ of diet: vitamin $\mathrm{A}, 3,300 \mathrm{IU}$; vitamin $\mathrm{D}_{3}, 440 \mathrm{IU}$; vitamin E, $22 \mathrm{IU}$; riboflavin, $2.2 \mathrm{mg}$; d-pantothenic acid, $13.2 \mathrm{mg}$; niacin, $17.6 \mathrm{mg}$; choline chloride, $110 \mathrm{mg}$; vitamin $\mathrm{B}_{12}, 22 \mu \mathrm{g}$; menadione sodium bisulfate, $2.2 \mathrm{mg}$; ethoxyquin, $4.4 \mathrm{mg}$.

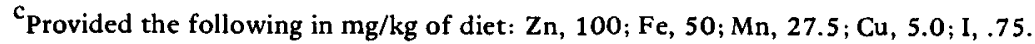


TABLE 3. PERFORMANCE OF GROWING-FINISHING SWINE FED VARIOUS DIETARY ARGININE:LYSINE RATIOSa

\begin{tabular}{|c|c|c|c|c|c|}
\hline $\begin{array}{l}\text { Treatment: } \\
\text { \% of NRC requirement for arginine: } \\
\text { Arginine:lysine ratio during growing phase: } \\
\text { Arginine:lysine ratio during finishing phase: } \\
\text { Item }\end{array}$ & $\begin{array}{l}1 \\
500 \\
1.43 \\
1.48\end{array}$ & $\begin{array}{l}2 \\
400 \\
1.14 \\
1.18\end{array}$ & $\begin{array}{l}3 \\
300 \\
.86 \\
.89\end{array}$ & $\begin{array}{l}4 \\
200 \\
.57 \\
.59\end{array}$ & $c V^{b}$ \\
\hline & \multicolumn{5}{|c|}{ Growing phase ( 27 to $44 \mathrm{~kg}$ ) } \\
\hline $\begin{array}{l}\text { Feed intake, } \mathrm{kg} / \mathrm{d}^{\mathrm{c}} \\
\text { Weight gain, } \mathrm{kg} / \mathrm{d} \\
\text { Gain/feed }\end{array}$ & $\begin{array}{l}1.77 \\
.59 \\
.338\end{array}$ & $\begin{array}{l}1.92 \\
.64 \\
.335\end{array}$ & $\begin{array}{l}1.87 \\
.63 \\
.335\end{array}$ & $\begin{array}{l}1.84 \\
.63 \\
.344\end{array}$ & $\begin{array}{l}5.33 \\
5.24 \\
6.57\end{array}$ \\
\hline & \multicolumn{5}{|c|}{ Finishing phase ( 44 to $97 \mathrm{~kg}$ ) } \\
\hline $\begin{array}{l}\text { Feed intake, } \mathrm{kg} / \mathrm{d} \\
\text { Weight gain, } \mathrm{kg} / \mathrm{d}^{\mathrm{c}} \\
\text { Gain/feed }\end{array}$ & $\begin{array}{l}3.09 \\
.77 \\
.251\end{array}$ & $\begin{array}{l}3.16 \\
.81 \\
.257\end{array}$ & $\begin{array}{l}3.19 \\
.82 \\
.257\end{array}$ & $\begin{array}{l}3.03 \\
.74 \\
.244\end{array}$ & $\begin{array}{l}7.61 \\
6.33 \\
4.42\end{array}$ \\
\hline & \multicolumn{5}{|c|}{ Total experiment ( 27 to $97 \mathrm{~kg}$ ) } \\
\hline $\begin{array}{l}\text { Feed intake, } \mathrm{kg} / \mathrm{d} \\
\text { Weight gain, } \mathrm{kg} / \mathrm{d}^{\mathrm{c}} \\
\text { Gain/feed }\end{array}$ & $\begin{array}{l}2.70 \\
.72 \\
.268\end{array}$ & $\begin{array}{l}2.80 \\
.76 \\
.273\end{array}$ & $\begin{array}{l}2.80 \\
.76 \\
.272\end{array}$ & $\begin{array}{l}2.68 \\
.71 \\
.265\end{array}$ & $\begin{array}{l}6.73 \\
5.56 \\
4.34\end{array}$ \\
\hline
\end{tabular}

\footnotetext{
${ }^{a}$ Values represent the mean of five replicates of eight pigs.

${ }^{\mathrm{b}}$ Coefficient of variation, \%.

${ }^{c}$ Quadratic effect $(P<.05)$.

${ }^{\mathrm{d}}$ Quadratic effect $(P<.10)$.
}

tent decreased. Both the decreased dietary arginine content and the decreased total dietary $\mathrm{N}$ content may have contributed to the reduction in plasma urea. Plasma arginine $(\mathrm{P}<.001)$ and ornithine $(\mathrm{P}<.01)$ also decreased linearly. Previous research with pigs (Mitchell et al., 1968) has shown that dietary excesses of amino acids result in accumulation of those amino

TABLE 4. CONCENTRATIONS (MG/DL) OF UREA AND AMINO ACIDS IN PLASMA OF FINISHING SWINE FED VARIOUS DIETARY ARGININE:LYSINE RATIOSa

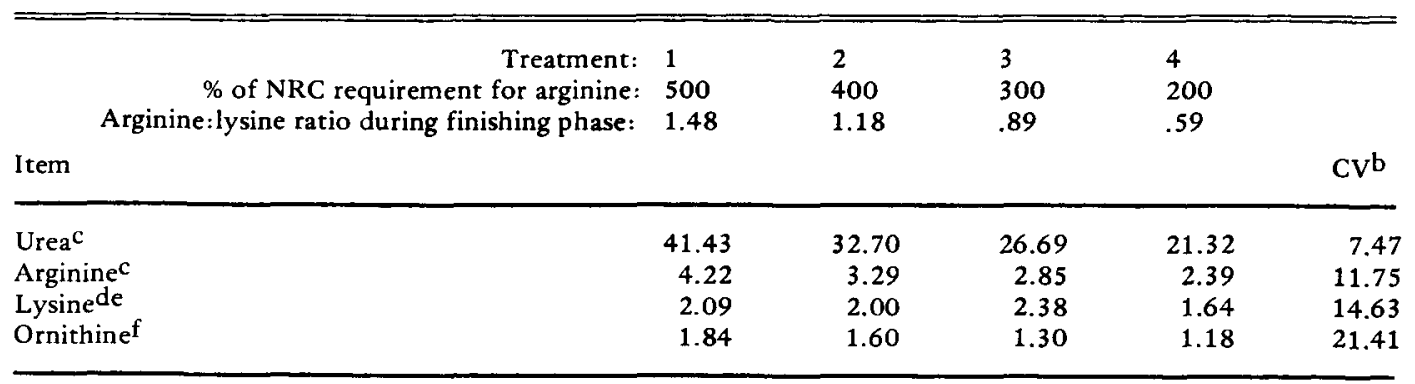

\footnotetext{
${ }^{a}$ Values represent the mean of five replicates of eight pigs for urea, and the mean of five replicates of a pooled sample of plasmas from eight pigs for amino acids.

${ }^{\mathrm{b}}$ Coefficient of variation, \%.

${ }^{c}$ Linear effect $(P<.001)$.

${ }^{\mathrm{d}}$ Quadratic effect $(P<.05)$.

${ }^{e}$ Cubic effect $(P<.05)$.

$f_{\text {Linear effect }}(P<.01)$.
} 
TABLE 5. CARCASS COMPOSITION OF FINISHING SWINE FED VARIOUS DIETARY ARGININE:LYSINE RATIOSa

\begin{tabular}{|c|c|c|c|c|c|}
\hline $\begin{array}{l}\text { Treatment: } \\
\text { \% of NRC requirement for arginine: } \\
\text { Arginine:lysine ratio during finishing phase: } \\
\text { Item }\end{array}$ & $\begin{array}{l}1 \\
500 \\
1.48\end{array}$ & $\begin{array}{l}2 \\
400 \\
1.18\end{array}$ & $\begin{array}{l}3 \\
300 \\
.89\end{array}$ & $\begin{array}{l}4 \\
200 \\
.59\end{array}$ & $\mathrm{CVb}$ \\
\hline Hot carcass wt, $\mathrm{kg}$ & 73.35 & 74.14 & 74.19 & 71.47 & 6.64 \\
\hline Adj. avg backfat thickness, $\mathrm{cm}^{\mathrm{c}}$ & 3.77 & 3.78 & 3.62 & 3.69 & 5.63 \\
\hline Adj. loin eye area, $\mathrm{cm}^{2} \mathrm{de}$ & 28.01 & 28.27 & 26.79 & 25.55 & 5.34 \\
\hline
\end{tabular}

${ }^{\mathrm{a}}$ Carcass composition was measured on barrows (28/treatment) only.

${ }^{\mathrm{b}}$ Coefficient of variation, $\%$.

${ }^{c}$ Adjusted by linear regression of hot carcass weight on average backfat.

$\mathrm{d}_{\text {Adjusted by linear regression of hot carcass weight on loin eye area. }}$

$\mathrm{e}_{\text {Linear effect }(P<.01) \text {. }}$

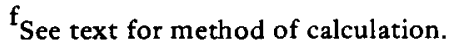

$\mathrm{g}_{\text {Linear effect }}(\mathrm{P}<.05)$.

acids in the plasma. The decrease in plasma ornithine probably reflects decreased urea cycle activity because of the reduction of arginine in the diet and plasma. Plasma lysine exhibited a quadratic and a cubic $(\mathrm{P}<.05)$ response to the dietary treatments. If one assumes that the supply of potentially absorbable lysine was the same for the four dietary treatments, plasma lysine would be expected to have increased as dietary arginine decreased if excess arginine interferes with lysine absorption in swine. The lack of a consistent increase in plasma lysine does not support the concept that the high dietary arginine levels present in natural ingredients used in swine diets interfere with lysine absorption. This conclusion is in contrast to that of Buraczewski et al. (1970), who reported that lysine or arginine reduced the absorption of the other amino acid. Their experiments, however, involved infusion of solutions of crystalline amino acids at levels 10 -fold greater than those found in normal diets.

Carcass composition data of the barrows are presented in table 5. Hot carcass weight and adjusted average backfat thickness were not different $(P>.10)$ among treatmerts. The adjusted loin eye area $(\mathrm{P}<.01)$ and percentage lean $(\mathrm{P}<$ $.05)$ decreased linearly as the dietary arginine level decreased. Evidently muscle deposition was not improved by reducing dietary arginine; in fact, the decrease in loin eye area is further evidence that lysine utilization was not favor- ably affected by reducing dietary arginine. The low crude protein content of treatment 4 may have influenced the lean percentage of pigs fed that treatment.

Thus, the high arginine content of normal swine diets can be reduced by varying the feed ingredients, while still meeting all essential amino acid requirements. However, in this experiment, there was little or no improvement in pig performance or carcass composition and no consistent increase in plasma lysine when arginine levels were varied over a wide range. It seems that there is little practical advantage in reducing the dietary arginine level below that which is found in conventional swine diets.

\section{Literature Cited}

AOAC. 1980. Official Methods of Analysis (13th Ed.). Association of Official Analytical Chemists, Washington, DC.

Benson, J. R. and P. E. Hare. 1975. o-Phthalaldehyde: Fluorogenic detection of primary amines in the picomole range. Comparison with fluorescamine and ninhydrin. Proc. Natl. Acad. Sci. USA 72:619.

Blackburn, S. 1978. Amino Acid Determination (2nd Ed.). Marcel Dekker Inc., New York.

Boorman, K. N. and H. Fisher. 1966. The argininelysine interaction in the chick. Brit. Poul. Sci. $7: 39$.

Buraczewski, S., A. G. Chamberlain, F. Horszczaruk and $T$. Zebrowska. 1970. Lysine and arginine interactions affecting their absorption from the duodenum of the pig. Proc. Nutr. Soc. 29:51A (Abstr.). 
Corley, J. R. and R. A. Easter. 1980. Lysine and tryptophan supplementation of low-protein diets for growing and finishing pigs. J. Anim. Sci. 51(Suppl. 1): 191 .

D'Mello, J.P.F. and D. Lewis. 1970. Amino acid interactions in chick nutrition. I. The interrelationship between lysine and arginine. Brit. Poul. Sci. 11:299.

Jones, J. D. 1964. Lysine-arginine antagonism in the chick. J. Nutr. 84:313.

Jones, J. D., S. J. Petersburg and P. C. Burnett. 1967. The mechanism of the lysine-arginine antagonism in the chick: Effect of lysine on digestion, kidney arginase, and liver transamidinase. J. Nutr. $93: 103$.

Marsh, W. H., B. Fingerhut and H. Miller. 1965. Automated and manual direct methods for the determination of blood urea. Clin. Chem. 11:624.

Matthews, D. M. 1975a. Intestinal absorption of peptides. Physiol. Rev. 55:537.

Matthews, D. M. 1975b. Protein absorption. Bibl. Nutr. Dieta 22:28.

Miller, E. R., J. Skomial, P. K. Ku and M. G. Hogberg. 1981. An evaluation of improving dietary amino acid balance of growing-finishing pigs. J. Anim.
Sci. 53(Suppl. 1): 93 .

Mitchell, J. R., Jr., D. E. Becker, A. H. Jensen, B. G. Harmon and H. W. Norton. 1968. Determination of amino acid needs of the young pig by nitrogen balance and plasma-free amino acids. J. Anim. Sci. 27:1327.

NPPC. 1976. Procedures to Evaluate Market Hogs. National Pork Producers Council, Des Moines, IA.

NRC. 1979. Nutrient Requirements of Domestic Animals, No. 2. Nutrient Requirements of Swine. Eighth Revised Ed. National Academy of Sciences-National Research Council, Washington, DC.

Parr Instrument Co. 1978. Instructions for the 1241 and 1242 adiabatic calorimeters. Manual No. 153. Parr Instrument Co., Moline, IL.

Perry, T. L. and S. Hansen. 1969. Technical pitfalls leading to errors in the quantitation of plasma amino acids. Clin. Chim. Acta 25:53.

SAS. 1979. SAS User's Guide. Statistical Analysis System Institute, Inc., Cary, NC.

Steel, R.G.D. and J. H. Torrie. 1980. Principles and Procedures of Statistics (2nd Ed.). McGraw-Hill Book Co., New York. 